University of Nebraska - Lincoln

DigitalCommons@University of Nebraska - Lincoln

\title{
Transformation of 2-line ferrihydrite to 6-line ferrihydrite under oxic and anoxic conditions
}

\author{
Ravi K. Kukkadapu \\ Pacific Northwest National Laboratory, ravi.kukkadapu@pnl.gov \\ John M. Zachara \\ Pacific Northwest National Laboratory \\ James K. Fredrickson \\ Pacific Northwest National Laboratory, jim.fredrickson@pnl.gov \\ Steven C. Smith \\ Pacific Northwest National Laboratory \\ Alice C. Dohnalkova \\ Pacific Northwest National Laboratory
}

See next page for additional authors

Follow this and additional works at: https://digitalcommons.unl.edu/usdoepub

Part of the Bioresource and Agricultural Engineering Commons

Kukkadapu, Ravi K.; Zachara, John M.; Fredrickson, James K.; Smith, Steven C.; Dohnalkova, Alice C.; and Russel, Colleen K., "Transformation of 2-line ferrihydrite to 6-line ferrihydrite under oxic and anoxic conditions" (2003). US Department of Energy Publications. 138.

https://digitalcommons.unl.edu/usdoepub/138

This Article is brought to you for free and open access by the U.S. Department of Energy at DigitalCommons@University of Nebraska - Lincoln. It has been accepted for inclusion in US Department of Energy Publications by an authorized administrator of DigitalCommons@University of Nebraska - Lincoln. 


\section{Authors}

Ravi K. Kukkadapu, John M. Zachara, James K. Fredrickson, Steven C. Smith, Alice C. Dohnalkova, and Colleen K. Russel 


\title{
Transformation of 2-line ferrihydrite to 6-line ferrihydrite under oxic and anoxic conditions
}

\author{
RaVi K. KUKKadaPU," John M. ZaChara, James K. Fredrickson, SteVen C. SMith, \\ Alice C. Dohnalkova, AND Colleen K. Russell
}

Pacific Northwest National Laboratory, Richland, Washington 99352, U.S.A.

\begin{abstract}
Mineralogical transformations of 2-line ferrihydrite were studied under oxic and $\mathrm{Fe}^{3+}$-reducing conditions to establish the role, if any, of 6-line ferrihydrite ("well" organized ferrihydrite) in the reaction pathway and as a final product. In oxic experiments, concentrated suspensions $(0.42 \mathrm{~mol} / \mathrm{L}$ $\mathrm{Fe}^{3+}$ in $0.1 \mathrm{~mol} / \mathrm{L} \mathrm{NaClO}_{4}$ ) of freshly synthesized 2-line ferrihydrite, with and without $3 \% \mathrm{Ni}^{2+}$, were aged at an initial $\mathrm{pH}=7.2$ (unbuffered and unadjusted) and $25^{\circ} \mathrm{C}$ for more than three years. X-ray diffraction, transmission electron microscopy, and Mössbauer spectroscopy measurements were performed on the solids after different aging periods. The primary mineralogical products observed were 6-line ferrihydrite and goethite, with minor hematite. Aggregation and crystallization of the 2line ferrihydrite liberated protons and depressed suspension $\mathrm{pH}$, but coprecipitated $\mathrm{Ni}^{2+}$ retarded this process. The joint, interrelated effects of $\mathrm{Ni}$ and $\mathrm{pH}$ influenced both the extent of conversion of 2line ferrihydrite and the identity of the major transformation products. Six-line ferrihydrite dominated in the $\mathrm{Ni}$ ferrihydrite suspension, whereas goethite dominated in the absence of $\mathrm{Ni}$. Aggregation-induced crystallization of 2-line ferrihydrite particles seemed responsible for 6-line ferrihydrite formation. Mineralogical changes to Ni ferrihydrite under anaerobic conditions were investigated at circumneutral $\mathrm{pH}$ using the $\mathrm{Fe}^{3+}$-reducing bacterium Shewanella putrefaciens. Residual 6-line ferrihydrite dominated bioreduced samples that also contained goethite and magnetite. The conversion of 2-line ferrihydrite to 6-line ferrihydrite was considerably more rapid under anaerobic conditions. The sorption of biogenic $\mathrm{Fe}^{2+}$ apparently induced intra-aggregate transformation of 2-line ferrihydrite to 6-line ferrihydrite. Collectively, abiotic and biotic studies indicated that 6-line ferrihydrite can be a transformation product of 2-line ferrihydrite, especially when 2-line ferrihydrite is undergoing transformation to more stable hematite or magnetite.
\end{abstract}

\section{INTRODUCTION}

Poorly crystalline $\mathrm{Fe}^{3+}$-oxides (ferrihydrites) that commonly exist in soils and sediments are thermodynamically unstable and, with time, transform to more crystalline $\mathrm{Fe}^{3+}$ oxides, e.g., goethite, hematite (Cornell and Schwertmann 1996). The transformation into crystalline $\mathrm{Fe}^{3+}$ oxides is widely believed to proceed via two competing mechanisms (Feitknecht and Michaelis 1962; Schwertmann and Murad 1983). Goethite formation involves the dissolution of ferrihydrite followed by nucleation and precipitation of the crystalline oxide in solution, whereas hematite forms through dehydration and internal atomic arrangement of the solid ferrihydrite, with less dependence on dissolution mechanism. The predominant mechanism depends primarily on suspension pH (Schwertmann and Murad 1983), with hematite formation achieving a maximum near $\mathrm{pH} 8$ and goethite near $\mathrm{pH} 4$ and 11.

Aggregation-based crystal growth and phase transformation has also been advanced as an alternative mechanism to explain the transformation of 2- to 3-nm ferrihydrite particles to polycrystalline $\mathrm{Fe}^{3+}$ oxides at $\mathrm{pH}$ conditions where the Fe-oxide phase is relatively insoluble (Banfield et al. 2000). Moreover,

* E-mail: ravi.kukkadapu@pnl.gov. Present address: Pacific Northwest National Laboratory, MSIN K8-96, P.O. Box 999, Richland, Washington 99352, U.S.A.

0003-004X/03/1112-1903\$05.00
Schwertmann et al. (1999) suggested that nano-particle aggregation was essential to induce crystallization of ferrihydrite to hematite. Ferrihydrite aggregation is maximal near the $\mathrm{pH}$ of zero net charge of the ferrihydrite "surface" ( $\mathrm{pH} \sim 8$ ), and crystallizing hematite nuclei are apparently supplied by a shortrange dissolution process involving precursor aggregates.

Synthetic and natural ferrihydrites are poorly ordered, but both exhibit a continuum in structure from amorphous to partly crystalline (Carlson and Schwertmann 1981; Cornell and Schwertmann 1996). Ferrihydrite exhibits a range of XRD patterns; the least crystalline variety exhibits two broad peaks (2line ferrihydrite), ${ }^{1}$ and the more crystalline variety exhibits six broad peaks (6-line ferrihydrite). Several structural models of 6-line ferrihydrite have been proposed, with the defective hematite structural model proposed by Chukrov et al. (1973) and Towe and Bradley (1967) being the most widely accepted. In contrast, Drits et al. (1993) proposed on the basis of XRD simulations that all natural and synthetic ferrihydrites are multi-component phases comprised of defect-free and defective ferrihydrite mixed with ultradisperse hematite. The main dif-

${ }^{1}$ The terms two-line ferrihydrite and HFO (hydrous ferric oxide) are commonly used synonymously (Cornell and Schwertmann 1996). The term HFO (e.g., Dzombak and Morel 1990) is applied to a material synthesized in the laboratory by rapid hydrolysis of a $\mathrm{Fe}^{3+}$ salt solution, with approximately $4-8 \mathrm{~h}$ aging at $\mathrm{pH} 7$.

This article is a U.S. government work, and is not subject to copyright in the United States. 
ference between 2-line ferrihydrite and 6-line ferrihydrite is the size of their coherent scattering domains.

Cornell and Schwertmann (1996) and Schwertmann et al. (1999) suggested that dilute suspensions of 2-line ferrihydrite do not transform to 6-line ferrihydrite with time, because these two forms of ferrihydrite precipitate under different conditions (e.g., Schwertmann and Cornell 1991; Schwertmann et al. 1999). In contrast, we recently observed the partial transformation of an aged 2-line $\mathrm{Ni}$ ferrihydrite $(\mathrm{Ni} /[\mathrm{Ni}+\mathrm{Fe}]$ mole fraction of $\sim 0.03$ ) to 6-line ferrihydrite in the presence of a dissimilatory iron-reducing bacterium (DIRB; Shewanella putrefaciens, strain $\mathrm{CN} 32$ ) at $25{ }^{\circ} \mathrm{C}$ in bicarbonate-buffered solution at circumneutral $\mathrm{pH}$ (Fredrickson et al. 2001). Our finding of 6-line ferrihydrite as a biotransformation product was consistent with the recently observed conversion of 2-line arsenate (As) ferrihydrite to 6-line As ferrihydrite in sediment (Rancourt et al. 2001).

Several authors have shown that 6-line ferrihydrite may convert to hematite with heat treatment (Johnston and Lewis 1983; Stanjek and Weidler 1992; Weidler 1995). Implied but not documented is that 6-line ferrihydrite may be an intermediate or metastable structure in the conversion of 2-line ferrihydrite to hematite. Recently, Schwertmann et al. (1999) attributed the transformation of an aqueous suspension of 6line ferrihydrite to hematite, without any transitional phases, to crystallization within ferrihydrite aggregates.

In the present work, experiments were performed to evaluate whether 2-line ferrihydrite transforms to 6-line ferrihydrite during conversion to more crystalline Fe oxides such as hematite and magnetite. Our objectives were to define: (1) whether 2-line ferrihydrite gradually crystallizes to a more organized phase (e.g., 6-line ferrihydrite) in aerobic and anaerobic environments, (2) the effect of small amounts of coprecipitated $\mathrm{Ni}^{2+}$ in ferrihydrite on such transformation, and (3) the commonality of 6-line ferrihydrite as an intermediate transformation product. These objectives were resolved by first performing aging experiments with concentrated suspensions $(0.42 \mathrm{~mol} / \mathrm{L})$ of freshly precipitated 2-line and 2-line Ni ferrihydrites in $0.1 \mathrm{~mol} /$ $\mathrm{L} \mathrm{NaClO}_{4}$. These were aged at $25^{\circ} \mathrm{C}$ and $\mathrm{pH} 7.2$ (initial) for 41 and 38 months, respectively. The aging conditions were chosen to promote the initial aggregation of ferrihydrite, and hence, hematite formation (Schwertmann and Fischer 1966; Fischer and Schwertmann 1975; Cornell and Giovanoli 1985; Schwertmann et al. 1999). The resulting mineral transformation products were characterized using a variety of techniques. Second, low-temperature Mössbauer measurements were performed on biotransformed Ni ferrihydrite from two incubations of Fredrickson et al. (2001) that produced different mineral associations with residual ferrihydrite. The combined results of these two experimental activities demonstrated that 6-line ferrihydrite can form as a transformation product of 2-line ferrihydrite under various conditions.

\section{MATERIALS AND METHODS}

\section{Materials}

The 2-line ferrihydrite and 2-line Ni ferrihydrite coprecipitates were prepared as described by Ainsworth et al. (1994) using $\mathrm{Fe}\left(\mathrm{NO}_{3}\right)_{3} \cdot 9 \mathrm{H}_{2} \mathrm{O}$ and
$\mathrm{Ni}\left(\mathrm{NO}_{3}\right)_{2} \cdot 6 \mathrm{H}_{2} \mathrm{O}$. The suspension $\mathrm{pH}$ was brought to 7.2 over the course of approximately $2 \mathrm{~h}$ using anoxic, $\mathrm{CO}_{2}$-free $2 \mathrm{~mol} / \mathrm{L} \mathrm{NaOH}$. The suspension $\mathrm{pH}$ remained almost constant during the $24 \mathrm{~h}$ after precipitation. For the $\mathrm{Ni}$ ferrihydrite, the mole proportions of $\mathrm{Fe}$ and $\mathrm{Ni}$ in solution before precipitation were 0.95 and 0.05 , respectively. The Fe ferrihydrite and Ni ferrihydrite were washed with anoxic, $\mathrm{CO}_{2}$-free $0.1 \mathrm{~mol} / \mathrm{L} \mathrm{NaClO}_{4}$ to remove nitrate, whose nitrate abundances were $<1 \mathrm{ppm}$. The suspensions consisting of ca. $0.42 \mathrm{~mol} / \mathrm{L}$ $\mathrm{Fe}^{3+}$ in $0.1 \mathrm{~mol} / \mathrm{L} \mathrm{NaClO}_{4}$ were aged in quiescent conditions under a nitrogen atmosphere at room temperature. The suspension $\mathrm{pH}$ of the Ni ferrihydrite was 5.0 after 38 months aging, and that of the Fe ferrihydrite was 2.9 after 41 months.

Aliquots of the Fe ferrihydrite and Ni ferrihydrite were aged for different lengths of time: 8 days ("fresh") and $8,17,35$, and 38 months for the $\mathrm{Ni}$ ferrihydrite coprecipitates, and 8 days ("fresh") and 17, 35, and 41 months for the Fe ferrihydrite. The "fresh" and aged ferrihydrite samples, with and without $\mathrm{Ni}$, were transferred to a vacuum filtration flask, rinsed with deionized water, and air-dried. The effects, if any, of air-drying on mineral transformation were assumed to be minimal. The air-dried samples were used for powder X-ray diffraction (XRD), Mössbauer spectroscopy, and transmission electron microscopy (TEM).

Aliquots of the $\mathrm{Ni}$ ferrihydrite suspension were dissolved completely in concentrated Ultrex ${ }^{\circledast} \mathrm{HCl}$, and analyzed by inductively coupled plasma mass spectroscopy (ICP-MS, Hewlett Packard 4500). The $[\mathrm{Fe}]_{\text {aq }}$ and $[\mathrm{Ni}]_{\mathrm{aq}}$ were determined simultaneously. These data allowed calculation of the $\mathrm{Ni} /(\mathrm{Ni}+\mathrm{Fe})$ ratio or $\chi_{\mathrm{Ni}}$ in the coprecipitates.

A subsample of the Ni ferrihydrite coprecipitate consisting of $\sim 0.01 \mathrm{~mol} / \mathrm{L}$ $\mathrm{Fe}^{3+}$ was treated with $100 \mathrm{~mL}$ of acidified $0.2-\mathrm{mol} / \mathrm{L}$ ammonium oxalate $(\mathrm{pH} 3.0$ with $\mathrm{HCl}$ ) solution for either 2 or $24 \mathrm{~h}$ at room temperature in light-excluded containers (Fey and LeRoux 1977). Following the desired extraction period, the suspension was centrifuged at $5000 \mathrm{rcf}$ for $10 \mathrm{~min}$. The supernatant was removed and filtered through a $0.2 \mu \mathrm{m}$ filter, and analyzed by ICP-MS for Fe and Ni. The ammonium oxalate-extracted $\mathrm{Ni}$ ferrihydrite residue was washed twice with $0.1 \mathrm{~mol} / \mathrm{L} \mathrm{NaClO}_{4}$ to remove dissolved metals, washed once with $0.1 \mathrm{~mol} /$ $\mathrm{L} \mathrm{NaHCO}_{3}$ to neutralize surface $\mathrm{pH}$, and then air-dried. The air-dried sample was used for XRD and Mössbauer. An aliquot of the 41 month aged 2-line Fe ferrihydrite suspension was treated similarly. Details about the isolation and culturing of bacteria, media composition, biotransformation experiments, and analyses (XRD and Mössbauer) of the bioreduced samples have been described previously (Fredrickson et al. 2001).

\section{METHODS}

Powder XRD patterns and Mössbauer measurements were obtained as described previously (Fredrickson et al. 2001; Kukkadapu et al. 2001). The, JADE+, V5 (Materials Data, Inc., Livermore, California) data analysis software package was used to subtract the XRD spectra of the ammonium-oxalate treated sample from the spectra of the untreated sample. All Mössbauer spectra were fitted (without thickness correction) with quadrupole splitting (QSDs) and/or hyperfine splitting distributions (HFDs) using the Voigt-based fitting method of Rancourt and Ping (1991). The following guidelines were used in the modeling of the Mössbauer data: (1) the Lorentzian half-width at half maximum (HWHM) was fixed at $0.097 \mathrm{~mm} / \mathrm{s}$, (2) all doublets were assumed to be symmetric, (3) for sextets, the ratio of the spectral areas of peak 1 to peak 3 was fixed at 3 and the ratio of the spectral areas of peak 2 to peak 3 was fixed at 2, and (4) no coupling of $\delta$ or center shift (CS) with the distributed hyperfine parameter ( $\Delta$ or QS), or coupling of quadrupole shift parameter $(\varepsilon)$ with the distributed hyperfine parameters $(\mathrm{z})$, were allowed.

A drop of dilute, sonicated mineral suspension was applied directly to a 200-mesh copper grid coated with carbon-sputtered Formvar support film for TEM studies. Samples were examined on a JEOL 2010 HR TEM at $200 \mathrm{kV}$. Imaging and analyses were performed at electron-transparent edges of sample aggregates. Selected Area Electron Diffraction (SAED) was performed on the ferrihydrite. Ring patterns were obtained using the smallest SAED aperture at $40 \mathrm{~s}$ for $d$ values smaller than $0.25 \mathrm{~nm}$ (errors $\pm 0.005 \mathrm{~nm}$ ). Both images and SAED patterns were digitally collected, and were analyzed using Digital Micrograph and Desktop Microscopist software.

\section{RESULTS}

In the results that follow we describe our finding of 6-line ferrihydrite as an apparent transformation product of 2-line ferrihydrite in three different systems: (1) Ni ferrihydrite aged under aerobic conditions, (2) Fe ferrihydrite aged under aero- 
bic conditions, and (3) Ni ferrihydrite incubated with an electron donor and an Fe-reducing bacterium under anoxic conditions. The intent of this presentation is to show that 6-line ferrihydrite was an unexpected, but common transformation product of 2-line ferrihydrite in suspensions that vary in $\mathrm{pH}$, salt, minor element content, redox potential, and organic compounds.

\section{Aerobic transformation of Ni ferrihydrite}

Chemical analyses and powder XRD. The $\mathrm{pH}$ of the $\mathrm{Ni}$ ferrihydrite suspension decreased from $\mathrm{pH} 7.2$ to $\mathrm{pH} 5.0$ with 35 months of aging. Aging, however, had little effect on the mole fraction of $\mathrm{Ni}\left(\chi_{\mathrm{Ni}}\right)$ of the coprecipitate. The $\chi_{\mathrm{Ni}}$ in the "fresh" sample was 0.038 , whereas that of the 35 month aged sample was 0.035 . The XRD patterns, on the other hand, changed significantly over the period of aging (Fig. 1). Two broad peaks, which are typical of 2-line ferrihydrite (Schwertmann and Cornell 1991), dominated the XRD patterns of the "fresh" (not shown), 8-, and 17 month aged samples (peaks at 0.22 to 0.25 and $0.15 \mathrm{~nm}$ ). In addition to the 2-line ferrihydrite peaks, a sharper peak centered around $0.25 \mathrm{~nm}$ that is characteristic of the $d(110)$ peak of 6-line ferrihydrite (Eggleton and Fitzpatrick 1988) was apparent in the 8 month aged sample (Fig. 1a). The intensity of this peak (d110) increased after 17 months of aging (Fig. 1b). Other incipient peaks attributable to 6-line ferrihydrite were also evident in the 17 month spectrum (Eggleton and Fitzpatrick 1988; Carlson and Schwertmann 1981). Overall, the diffraction features in Figs. $1 \mathrm{a}$ and $1 \mathrm{~b}$ implied the co-existence of 2-line ferrihydrite and 6line ferrihydrite, with the latter increasing with aging time. The 6-line ferrihydrite contribution dominated the diffractogram of the 35 month sample (Fig. 1c). In addition to 6-line ferrihydrite, peaks assignable to goethite and hematite were also evident. The broad feature at $29^{\circ} 2 \theta(0.31 \mathrm{~nm})$ evident in the 8 - and 17 month samples was noticeably absent in the 35 month sample, implying a decrease in the content of 2-line ferrihydrite.

Ammonium oxalate treatment. A 38 month aged $\mathrm{Ni}$ ferrihydrite, which displayed an XRD pattern identical to that of the 35 month sample (Fig. 2a; compare with Fig. 1c), was obtained after treatment with acid ammonium oxalate for 2 or $24 \mathrm{~h}$. Both 2- and 6-line synthetic ferrihydrite dissolve quickly in acidified ammonium oxalate (Schwertmann 1959; Schwertmann and Fischer 1973; Eggleton and Fitzpatrick 1988). The treatment is used to separate poorly crystalline $\mathrm{Fe}^{3+}$ oxides (ferrihydrites) from crystalline ones (goethite, hematite, or lepidocrocite) because the latter are less affected by the reagent (Schwertmann et al. 1982). Both the 2 and 24 h treatments dissolved similar amounts of $\mathrm{Fe}$ and $\mathrm{Ni}(75 \%$ of $\mathrm{Fe}$ and $65 \%$ of $\mathrm{Ni}$ for the $2 \mathrm{~h}$ treatment, and $80 \% \mathrm{Fe}$ and $73 \% \mathrm{Ni}$ for the $24 \mathrm{~h}$ treatment), implying that the mineral mixture consisted of 20 to $25 \%$ crystalline compounds.

The residual mineral fraction after oxalate extraction contained goethite and hematite (Fig. 2b). The difference pattern between the untreated and treated sample (Fig. 2c) displayed peaks that matched with those for 6-line ferrihydrite (Eggleton and Fitzpatrick 1988, Carlson and Schwertmann 1981) (Fig. 2c). Differential XRD following oxalate treatment is routinely performed to identify ferrihydrite in soils (Schulze 1994). The
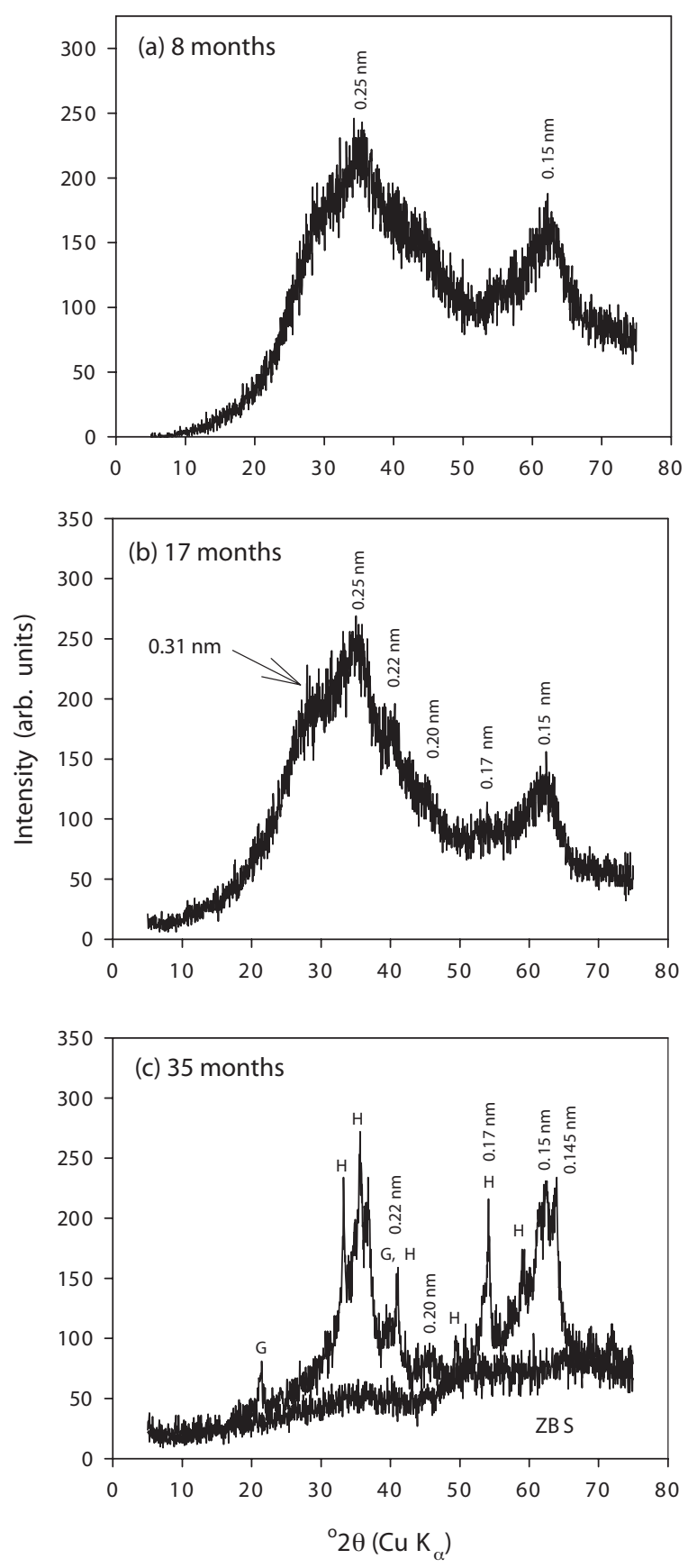

FIGURE 1. Powder XRD patterns of "aged" Ni ferrihydrite. (a) 8 months, (b) 17 months, and (c) 35 months. A diffractogram of a zerobackground slide (ZBS) is included in Figure 1c. G and H in Figure 1c label goethite and hematite.

relative intensities of the peaks in Figure $2 c$, however, were different from those of typical 6-line ferrihydrite, possibly because the two broad peaks of residual 2-line ferrihydrite were buried under the 6-line pattern. The buried 2-line feature made it difficult to resolve the fifth and sixth lines of 6-line ferrihydrite. Eggleton and Fitzpatrick (1998) interpreted the asymmetry on the low-angle side of the $d(110)$ reflection $(36.2$ 
${ }^{\circ} 2 \theta$ ) of 6-line ferrihydrite to result from 2-line ferrihydrite. The difference pattern in Figure $2 \mathrm{c}$ also displays the presence of two small, broad peaks at 0.45 and $0.32 \mathrm{~nm}$. These peaks at 0.45 and $0.32 \mathrm{~nm}$ are not readily evident in Figure 2c, but are detectable from counts. Some believe (Towe and Bradley 1967; Eggleton and Fitzpatrick 1988) that they represent the $d(002)$ and $d(003)$ peaks of 6-line ferrihydrite. The first major peak of the 6-line pattern $\left[d(110)\right.$ peak at $36^{\circ} 2 \theta$, or $d$-value of 0.25 $\mathrm{nm}]$ had a half-width at half maximum (HWHM) of $\sim 3{ }^{\circ} 2 \theta$. The HWHM of the $d(110)$ line increases with decreasing crystallinity, and Carlson and Schwertmann (1981) have reported HWHM values in the range of 6 to $16^{\circ} 2 \theta$ for Si ferrihydrites.

Electron microscopy. The 35 month aged Ni ferrihydrite was analyzed by TEM to obtain microscopic evidence for the presence of both 2-line and 6-line ferrihydrite. In Figure 3a,

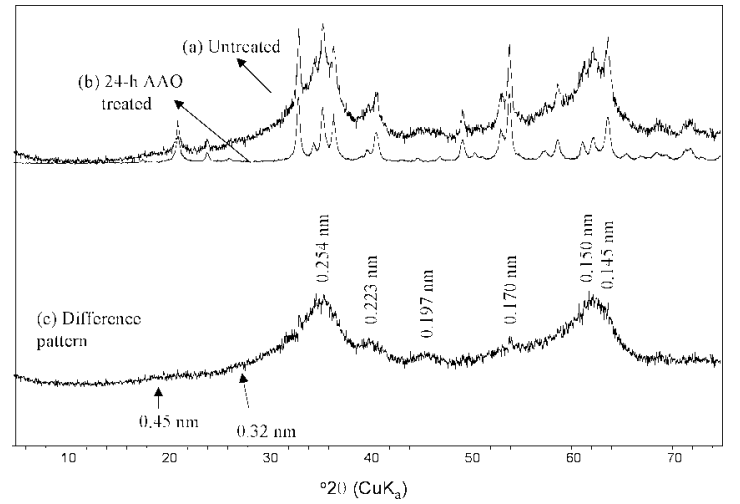

FIGURE 2. Powder XRD patterns of the 38 month aged Ni ferrihydrite before and after $24 \mathrm{~h}$ AAO treatment, and the difference pattern.

\section{(a) Micrograph}

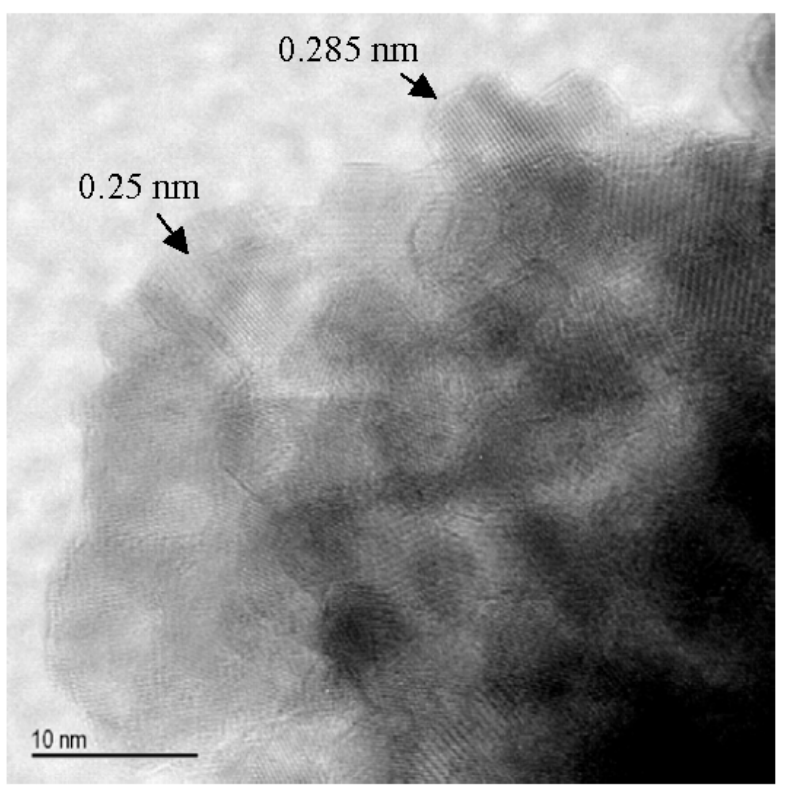

pseudo-hexagonal crystallites with an average size of 6 to 10 $\mathrm{nm}$ were evident that were typical of 6-line ferrihydrite. The crystallites exhibited lattice fringes consistent with 6-line ferrihydrite at $0.25 \mathrm{~nm}$ and $0.285 \mathrm{~nm}$. The crystallite morphology was similar to that of the 6-line ferrihydrite reported by Janney et al. (2000). An SAED pattern of these crystals (Fig. $3 \mathrm{~b}$ ) displayed $d$ values (for the diffuse rings) that were within errors of determination from those reported for 6-line ferrihydrite (Janney et al. 2000).

Selected areas in the 35 month Ni ferrihydrite also showed the presence of 2-line ferrihydrite (Figs. $4 \mathrm{a}$ and $4 \mathrm{~b}$ ). The crystallites were 2 to 4 times smaller than those of 6-line $\mathrm{Ni}$ ferrihydrite (Fig. 4a) and did not exhibit coherent domains. The SAED pattern displayed two bright rings with shoulders on each side, identical to the 2-line ferrihydrite of Janney et al. (2000). In addition to the 2- and 6-line ferrihydrite, the micrographs displayed regions that were rich in acicular goethite crystals ( $\sim 30 \mathrm{~nm}$ long, top right corner, Fig. 4a) and hexagonally shaped hematite (not shown).

Mössbauer spectroscopy. Room-temperature Mössbauer measurements, alone, are not adequate to characterize crystallinity of ferrihydrite (Murad 1996) because 2-line ferrihydrite exhibits a doublet feature both at room temperature and $77 \mathrm{~K}$, whereas 6-line ferrihydrite exhibits a doublet only at room temperature. A "collapsed" sextet dominates the spectrum of 6line ferrihydrite at $77 \mathrm{~K}$ (Murad 1996). The presence of a doublet in the room temperature and $77 \mathrm{~K}$ spectra of the "fresh" Ni ferrihydrite (Figs. 5a and 5d) indicated that it was the 2-line form.

A "collapsed" sextet feature that is characteristic of 6-line ferrihydrite, however, was evident in the $77 \mathrm{~K}$ spectra of the 17- and 35 month aged samples (Figs. 5e and 5f, black trace),

\section{(b) SAED pattern}

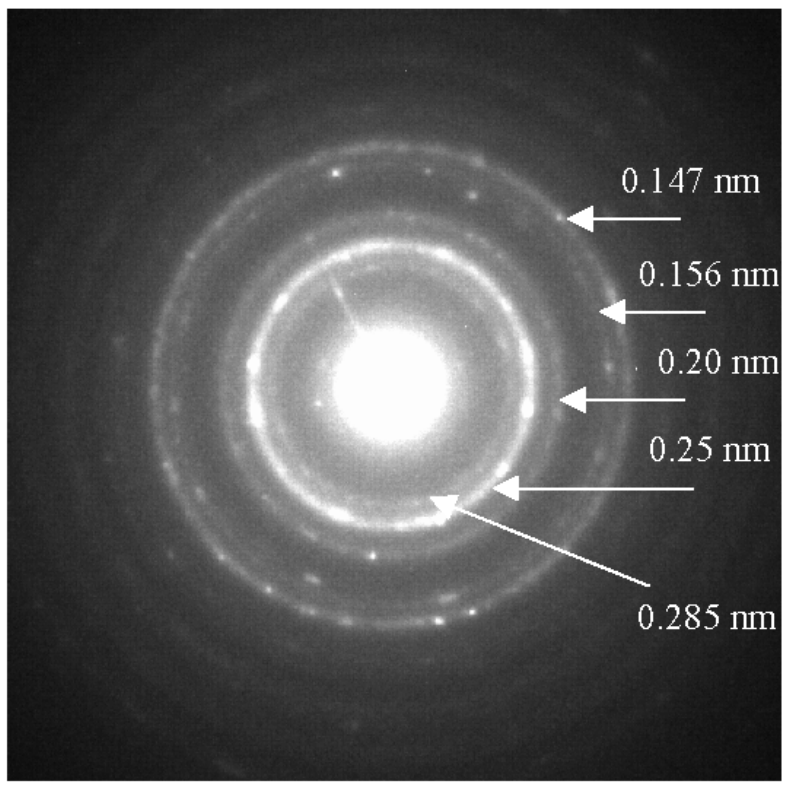

FIGURE 3. TEM of 35 month aged Ni ferrihydrite: (a) hexagonal crystals of 6-line Ni ferrihydrite that range from 6 to $10 \mathrm{~nm}$, and lattice fringes and (b) SAED with $d$-values of rings. 
in agreement with XRD observations (Fig. 1). The 8 month sample exhibited spectra similar to those of the 17 month sample (not shown). Note that in the 17 month sample, only a doublet feature was evident in the room temperature spectrum (Fig. $5 b)$. In addition to the "collapsed" sextet feature (6-line ferrihydrite), two minor sextets attributable to goethite (inner sextet) and hematite (outer sextet) were also present in the 77 $\mathrm{K}$ spectra of the aged samples. The contribution of both goethite and hematite to the spectra was greater in the 35 month sample (Fig. 5f, black trace). The presence of hematite and goethite in the 35 month was also evident in room temperature spectrum of the 35 month aged sample (* and + in Fig. 5c). A comparison of the Mössbauer spectrum of the $24 \mathrm{~h}$ AAO treated 35 month sample with the untreated one (Fig. 5f) revealed that (1) the bulk of the 35 month aged sample (untreated) was 6line ferrihydrite (in accordance with XRD), (2) AAO preferentially dissolved 6-line ferrihydrite without significantly affecting the crystallinity of goethite and hematite, and (3) the Mössbauer signature of goethite and hematite in the $24 \mathrm{~h}$ AAO sample was very similar to the crystalline $\mathrm{Fe}^{3+}$ oxide fraction in the untreated sample.

A two-Gaussian QSD fit was used to model the room temperature and $77 \mathrm{~K}$ spectra of the "fresh" sample (Figs. 5a and $5 \mathrm{~d})$. The QS of maximum probability deduced from the QSD corresponds to the average $\mathrm{Fe}^{3+}$ distortion and the width of the distribution corresponds to the variation in $\mathrm{Fe}^{3+}$ site geometry (Rancourt 1988; Murad 1996; Rancourt et al. 1994). The derived Mössbauer parameters are shown in Table 1. The room temperature parameters were similar to those recently reported for a room temperature spectrum of a synthetic 2-line ferrihydrite, and are typical of $\mathrm{Fe}^{3+}$ in octahedral coordination (Rancourt et al. 2001). The assignment of $\mathrm{Fe}^{3+}$ sites to octahe- dral coordination is in agreement with the Mössbauer spectroscopy data of ferrihydrite by Pankhurst and Pollard (1992). The objective of the modeling of the $77 \mathrm{~K}$ spectrum was to utilize its fit parameters in describing the 35 month aged sample (discussed below).

A combined QSD + HFD model was used to fit the $77 \mathrm{~K}$ spectra of the 35 month aged samples (untreated and $24 \mathrm{~h} \mathrm{AAO;}$ Fig. 6, Table 1). In these, it was possible to resolve the contributions from various sites with certain assumptions. The objective of the spectral modeling of the AAO-treated sample (Fig. 6a) was to identify the Mössbauer parameters of Ni goethite and Ni hematite that could be used along with those for 2-line $\mathrm{Ni}$ ferrihydrite to qualitatively estimate (assuming identical $f$ factors for all phases) the contribution of 6-line ferrihydrite to the untreated sample (Fig. 6b). A two-Gaussian component distribution was used to model the 6-line ferrihydrite contribution (Fig. 6c; Table 1). The derived relative areas of goethite and hematite together were $20 \%$ in the 35 month aged $\mathrm{Ni}$ ferrihydrite, a value that agreed well with the crystalline Fe(III) oxide content estimated from AAO treatment. The computed spectral areas of 2-line and 6-line ferrihydrite were 15 and 65\%, respectively, in the same sample. The $<\varepsilon>$ value of 0.21 in for hematite indicated that the phase was highly crystalline (Dang et al. 1998).

\section{Aerobic transformation of Fe ferrihydrite}

The $\mathrm{pH}$ of the $\mathrm{Fe}$ ferrihydrite suspension decreased more with aging than did the $\mathrm{Ni}$ ferrihydrite suspension. The $\mathrm{pH}$ of the "fresh" Fe ferrihydrite suspension was 7.2, and that of the 41 month aged suspension was 2.9. Powder XRD of the "fresh" sample revealed the presence of two broad peaks ( 0.22 to 0.25 and $0.15 \mathrm{~nm}$ ) characteristic of 2-line ferrihydrite (Fig. 7a). The

\section{(a) Micrograph}

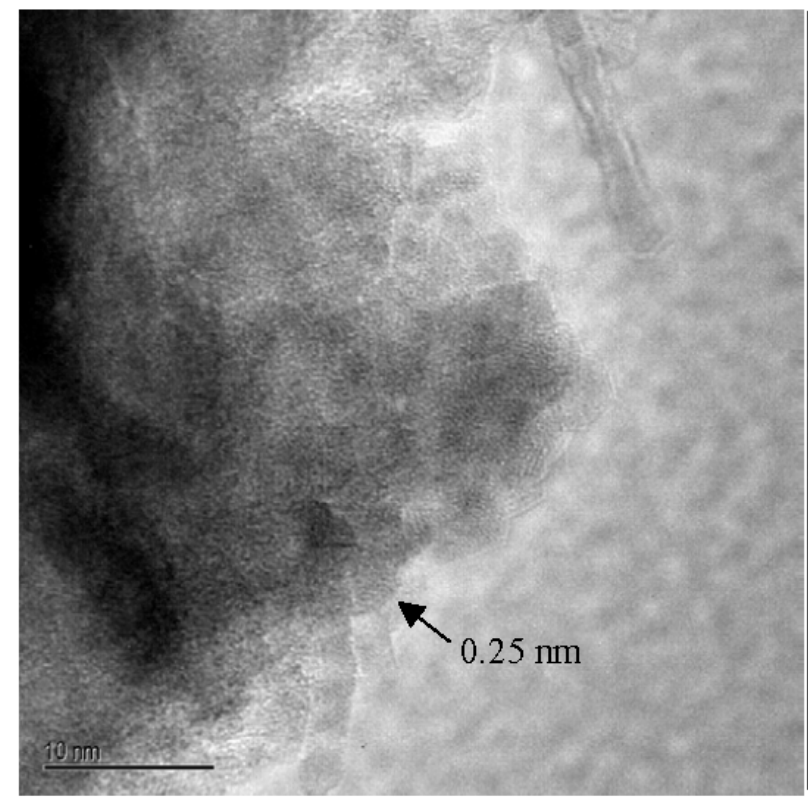

\section{(b) SAED pattern}

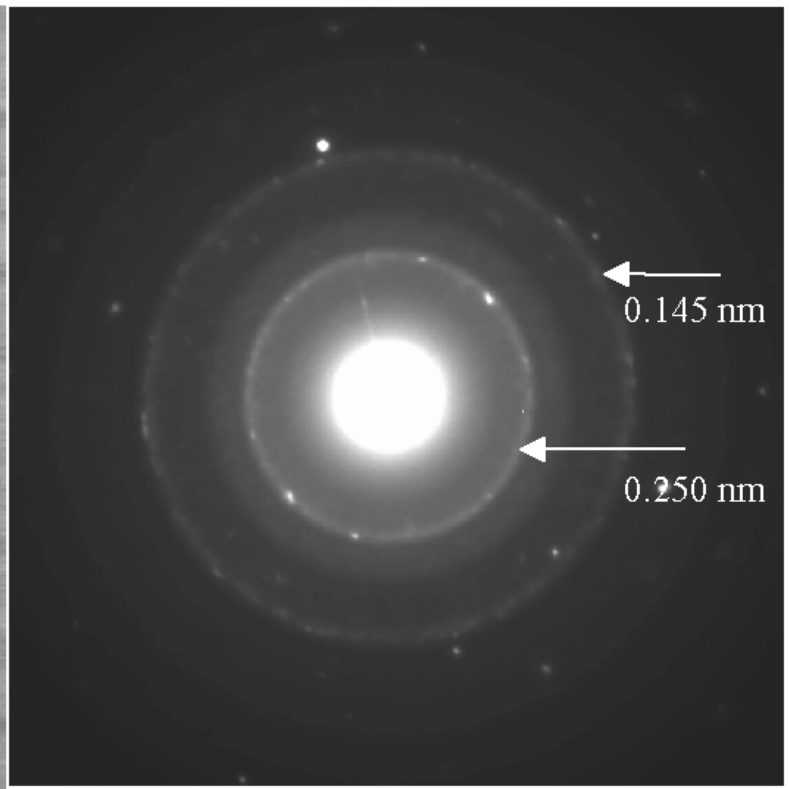

FIGURE 4. TEM of 35 month aged Ni ferrihydrite: (a) small crystals of 2-line Ni ferrihydrite (up to 4 nm) and (b) SAED with $d$-values of rings. 


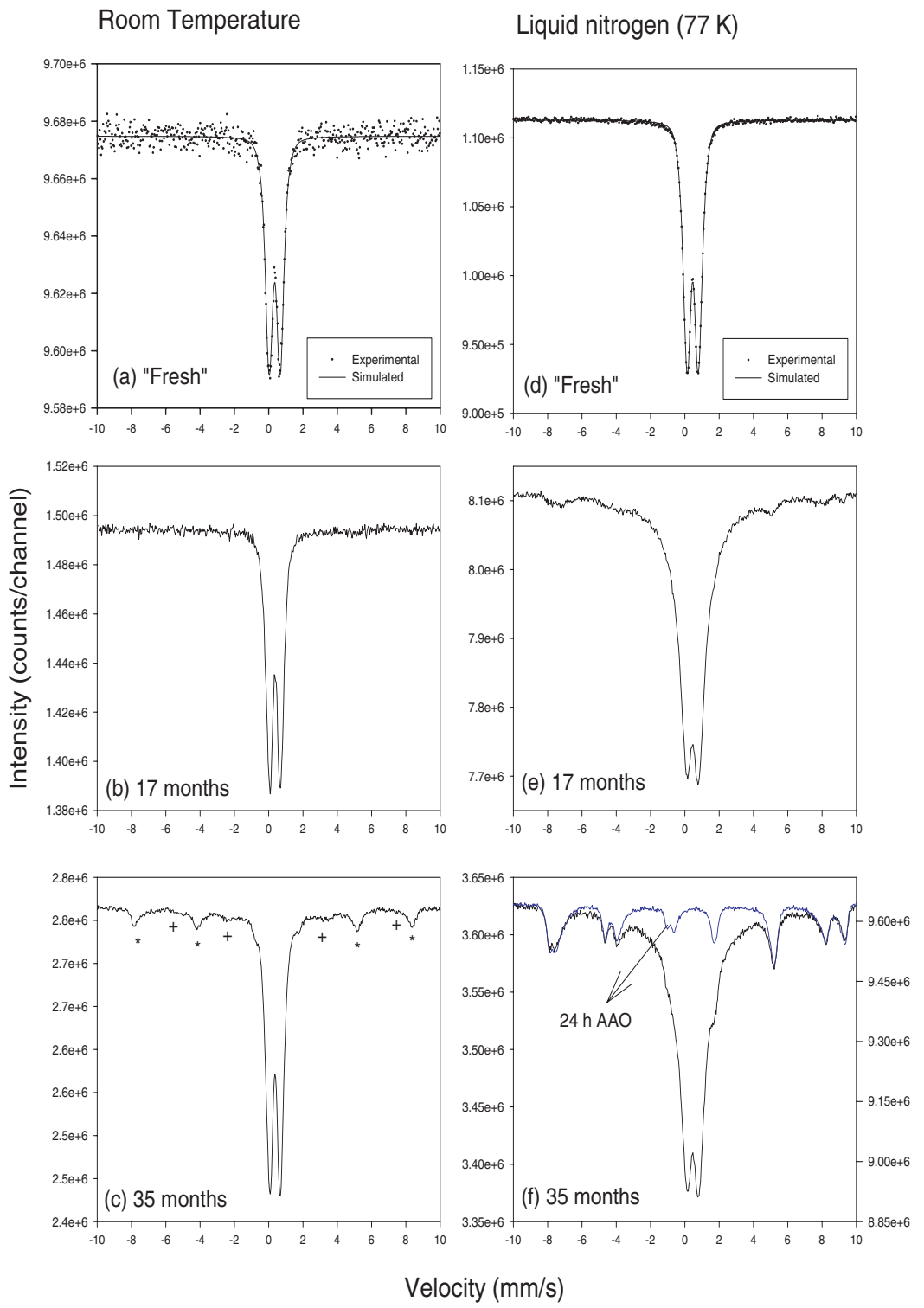

FIGURE 5. Room-temperature (a-c) and liquid nitrogen (d-f) Mössbauer spectra of "fresh" and aged $\mathrm{Ni}$ ferrihydrite samples. The Mössbauer spectrum of the $24 \mathrm{~h}$ AAO extracted, 35 month sample is shown in Figure $5 \mathrm{f}$ (in gray).

TABLE 1. Mössbauer parameters for various ferrihydrites and reacted ferrihydrite samples

\begin{tabular}{|c|c|c|c|c|c|}
\hline Sample & Fe-mineral & $\begin{array}{l}<\mathrm{CS}> \\
(\mathrm{mm} / \mathrm{s})\end{array}$ & $\begin{array}{l}<Q S> \\
(\mathrm{mm} / \mathrm{s})\end{array}$ & $\begin{array}{c}<\varepsilon> \\
(\mathrm{mm} / \mathrm{s})\end{array}$ & $\begin{array}{l}<B_{\mathrm{h}>}> \\
\text { (Tesla) }\end{array}$ \\
\hline \multicolumn{6}{|c|}{ Aerobic - Ni ferrihydrite } \\
\hline "Fresh" (RT- spectrum) & 2-line ferrihydrite & 0.34 & 0.71 & - & - \\
\hline "Fresh" (77 K spectrum) & 2-line ferrihydrite & 0.46 & 0.72 & - & - \\
\hline \multirow[t]{2}{*}{ 24-h AAO/35-month (77 K) } & Ni goethite & 0.49 & - & -0.1 & 47.6 \\
\hline & Ni hematite & 0.52 & - & 0.21 & 53 \\
\hline \multirow[t]{4}{*}{ 35-month (untreated) $(77 \mathrm{~K})$} & Ni geothite & 0.49 & - & -0.1 & 47.6 \\
\hline & Ni hematite & 0.52 & - & 0.21 & 53 \\
\hline & 2-line ferrihydrite & 0.46 & 0.72 & - & - \\
\hline & 6-line ferrihydrite & 0.46 & - & -0.006 & 13.4 \\
\hline \multicolumn{6}{|c|}{ Aerobic - Fe ferrihydrite } \\
\hline \multirow[t]{2}{*}{ 41-month (untreated) (77 K) } & goethite & 0.47 & - & -0.13 & 49 \\
\hline & 6-line ferrihydrite & 0.43 & - & -0.02 & 21.5 \\
\hline \multicolumn{6}{|c|}{ Anaerobic - Ni ferrhydrite } \\
\hline \multirow[t]{3}{*}{ Bioreduced in $\mathrm{HCO}_{3}{ }^{-}$buffer $(77 \mathrm{~K})$} & goethite & 0.49 & - & -0.11 & 47.3 \\
\hline & 2-line ferrihydrite & 0.45 & 0.73 & - & - \\
\hline & 6 -line ferrihydrite & 0.46 & - & -0.006 & 16.61 \\
\hline
\end{tabular}



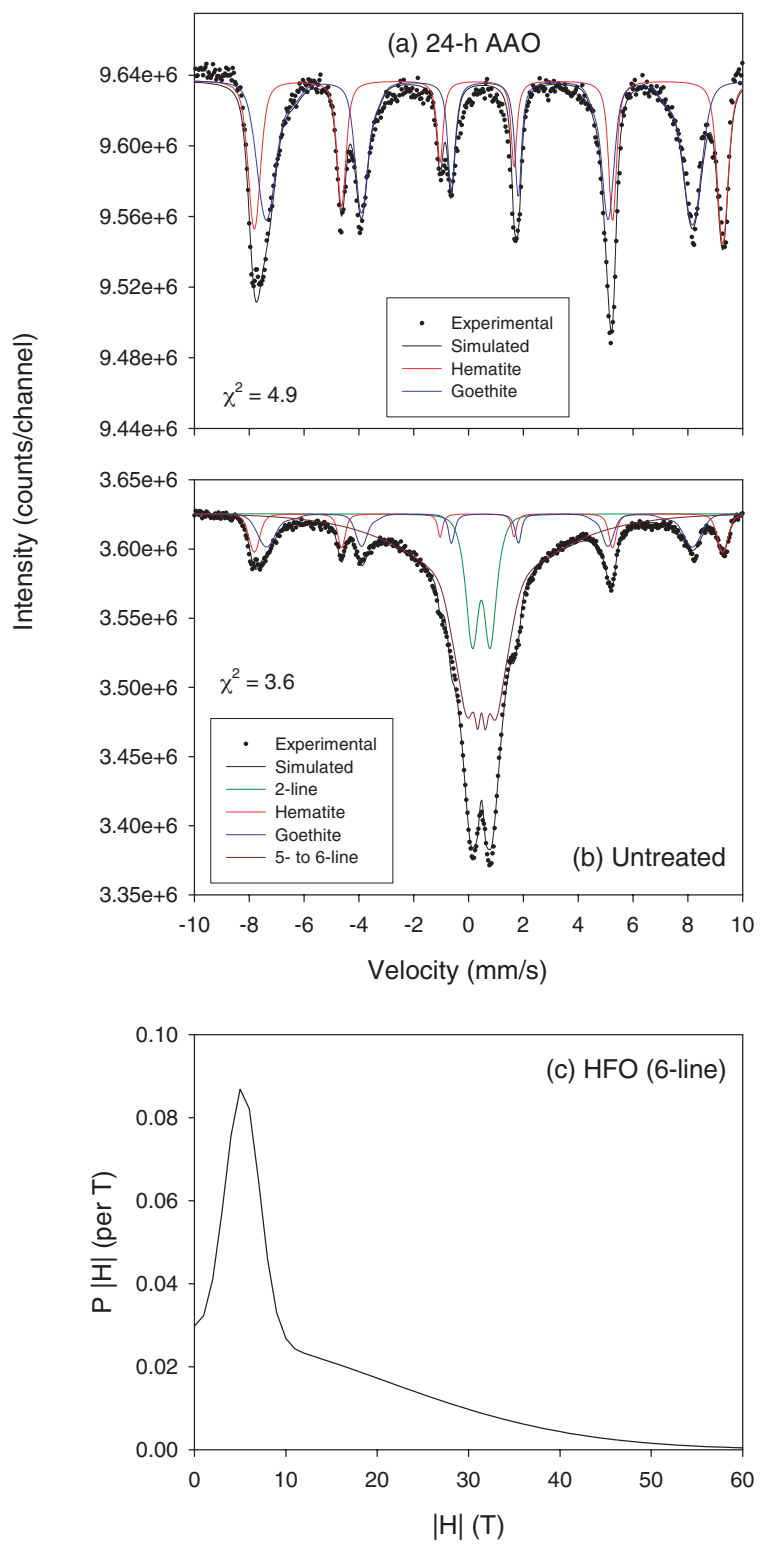

FIGURE 6. Experimental and simulated $77 \mathrm{~K}$ Mössbauer spectra of Ni ferrihydrite (a) the $24 \mathrm{~h} \mathrm{AAO} / 35$-month aged sample, (b) the untreated 35-month sample, (c) HFD distribution of 6-line component of $77 \mathrm{~K} 35$ month sample.

additional broad peak at $0.25 \mathrm{~nm}$ in the spectrum was due to glycerol; this particular diffraction pattern was the only one collected in presence of glycerol. The 17 month sample differed considerably in its diffraction pattern from Ni ferrihydrite (Fig. 7b, compare with Fig. 1b). Sharp peaks that were characteristic of goethite dominated its spectrum ( $\mathrm{G}$ in Fig. 7b), in contrast to the Ni ferrihydrite. Diffraction maxima due to 6line ferrihydrite that dominated in the Ni ferrihydrite were far less prominent. The goethite content increased significantly with continued aging. Goethite dominated the spectrum of the 35 month (Fig. 7c) and 41 month (Fig. 8a) samples.

Acid ammonium oxalate extraction was carried out on the
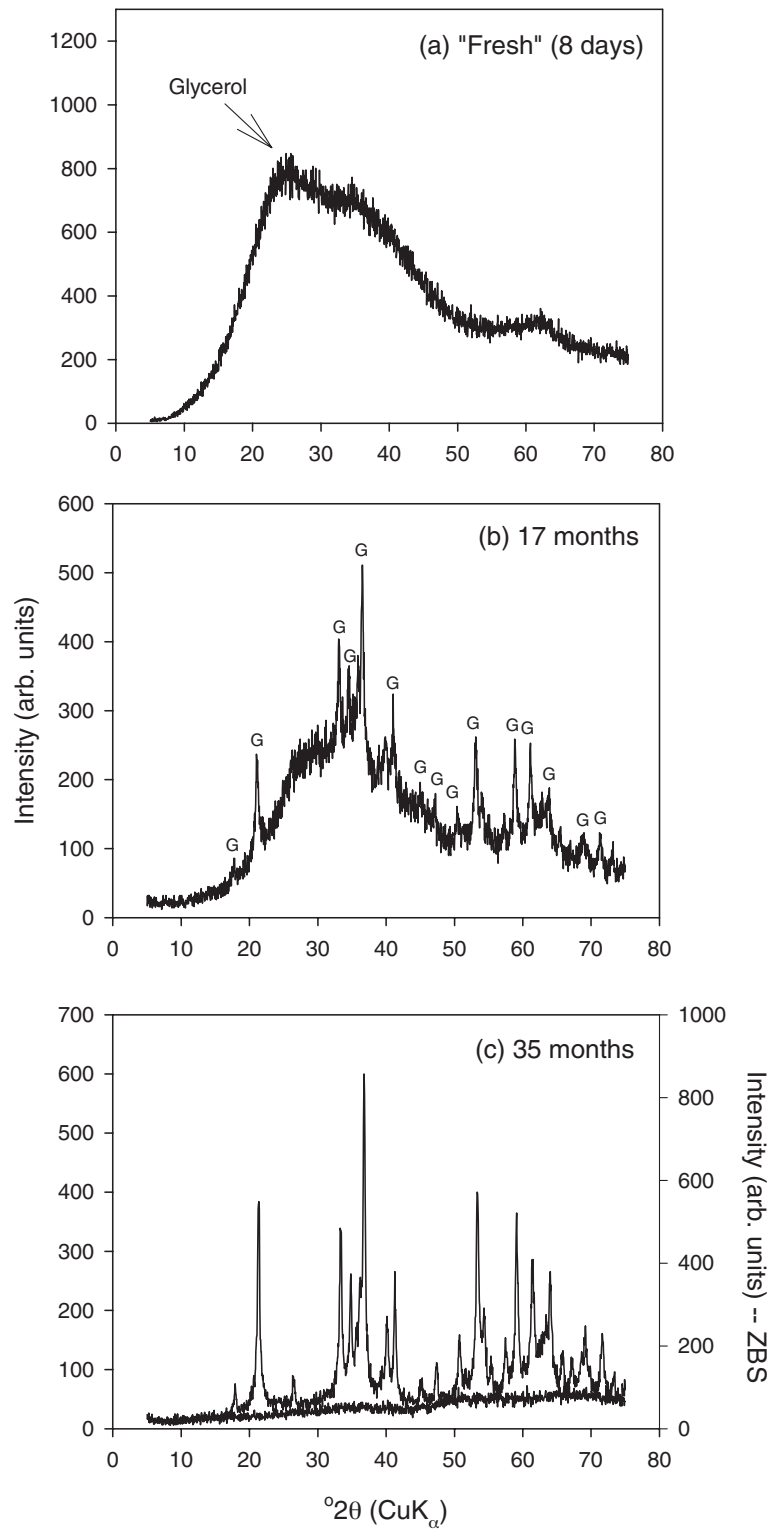

FIGURE 7. Powder XRD patterns of "aged" Fe ferrihydrite: (a) "fresh" (8 days), (b) 17 months, and (c) 35 months. G in Figure 7b labels goethite. The peak at $26^{\circ} 2 \theta$ in the "fresh" sample is from glycerol.

41 month sample (Fig. 8a) to identify the nature of the residual ferrihydrite. Approximately 33 and $41 \%$ of Fe was dissolved in 2 and $24 \mathrm{~h}$ treatments, a value that was considerably less than for the 38 month aged Ni ferrihydrite ( 75\%). An XRD spectrum of the $24 \mathrm{~h}$ ammonium oxalate-treated sample displayed peaks primarily from goethite (Fig. 8b). A comparison of the untreated and oxalate-treated samples revealed that the crystallinity (based on line widths) of the goethite was unaffected by AAO treatment. The difference pattern between the untreated and treated samples displayed peaks (Fig. 8c) that matched well with those of 6-line ferrihydrite (Eggleton and Fitzpatrick 1988). Little, if any contribution of 2-line 
ferrihydrite was noted to the difference pattern.

Mössbauer spectroscopy. Room temperature and $77 \mathrm{~K}$ Mössbauer measurements of the 41 month aged ferrihydrite displayed the presence of residual ferrihydrite that was removed by AAO treatment (Fig. 9). The contribution of this phase to the $77 \mathrm{~K}$ spectrum (Fig. 9c) was described with a collapsed sextet, consistent with 6-line ferrihydrite, and the noted HFD distribution (Fig. 9d). Two-line ferrihydrite was not included in the fit because its presence was not indicated by XRD. The sextet was assigned to goethite, based on XRD data. As noted for Ni ferrihydrite, AAO removed 6-line ferrihydrite (the collapsed sextet feature in the $77 \mathrm{~K}$ spectrum) without significantly affecting the crystallinity of goethite. The Mössbauer signature of goethite in the AAO- treated sample was virtually identical to that of the crystalline $\mathrm{Fe}^{3+}$ oxide fraction in the untreated sample. The differences in the HFD distributions for 6line ferrihydrite in the Fe ferrihydrite and $\mathrm{Ni}$ ferrihydrite samples were attributed to variation in the superparamagnetic behavior of these solids. Coprecipitated metal ions affect superparamagnetic character of ferrihydrite by decreasing interactions between surface unpaired $\mathrm{Fe}^{3+}$ spins of the ferrihydrite particles (Zhao et al. 1996).

\section{Bioreductive transformation of $\mathrm{Ni}$ ferrihydrite}

Recently, we studied the biotransformation of 14 month aged Ni ferrihydrite by Shewanella putrefaciens, strain CN32, under anoxic conditions (Fredrickson et al. 2001). The starting material was primarily 2-line ferrihydrite, but showed incipient 6-line diffraction features like those of the 17 month aged $\mathrm{Ni}$ ferrihydrite (Fig. 1b). Incubations with the 14 month $\mathrm{Ni}$ ferrihydrite $\left(0.05 \mathrm{~mol} / \mathrm{L} \mathrm{Fe}^{3+}\right)$ and $\mathrm{CN} 32$ were carried out for 32 days at circumneutral $\mathrm{pH}$ with lactate $(0.03 \mathrm{~mol} / \mathrm{L})$ as the electron donor under various media and buffer conditions (0.03 $\mathrm{mol} / \mathrm{L}$ bicarbonate or PIPES). CN32 oxidizes lactate to acetate and bicarbonate, and disposes of electron equivalents to ferrihydrite, the electron acceptor. This microbiologically mediated electron transfer reaction causes reduction of $\mathrm{Fe}^{3+}$ to $\mathrm{Fe}^{2+}$.

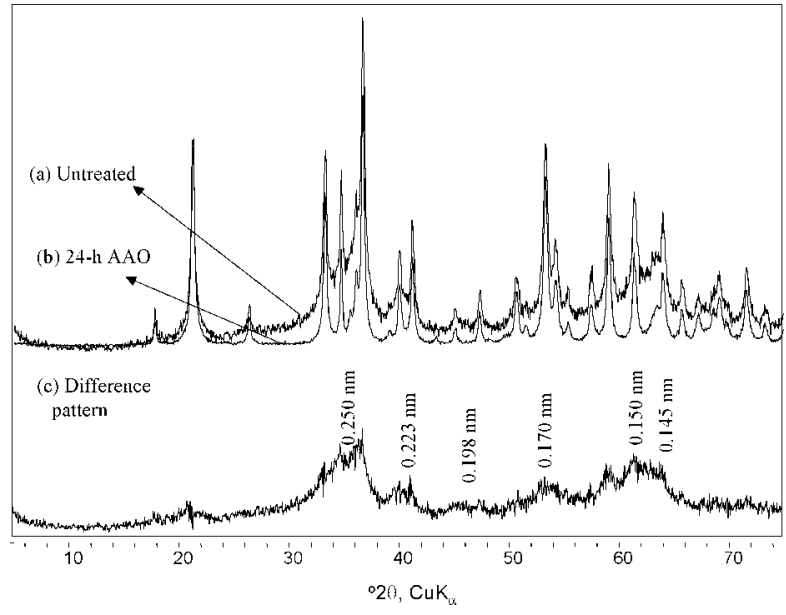

FIGURE 8. Powder XRD patterns of 41 month aged Fe ferrihydrite before and after 24 hour AAO treatment, and the difference pattern. Peaks other than 6-line in the difference pattern are artifacts of the subtraction procedure.
The $\mathrm{Fe}^{2+}$ so generated is reactive with the residual ferrihydrite (Zachara et al. 2002). A variety of mineral conversion products was observed, and the products were most dependent on the presence or absence of phosphate $(\mathrm{P})$ or anthraquinone disulfonate (AQDS), a quinone that facilitates ferrihydrite reduction (Nevin and Lovley 2000). These mineral transformation products included magnetite, siderite, vivianite, goethite, and 6-line ferrihydrite.

In Fredrickson et al. (2001), limited discussion was given to the formation of 6-line ferrihydrite because the paper had other objectives. One XRD analysis was presented from the incubation that yielded 6-line ferrihydrite as a primary biotransformation product (bicarbonate, no AQDS, no P). Here we utilize newly collected $77 \mathrm{~K}$ Mössbauer data (bicarbonate, no AQDS, no P) from that phase association (Fig. 10) to draw comparisons to those obtained through aerobic ferrihydrite aging presented in previous sections. Additionally, Mössbauer data are presented for a mineral residue from another incubation in that series (PIPES, AQDS, no P) that yielded magnetite as a primary biotransformation product in association with residual ferrihydrite (Fig. 11). Our intent in presenting these unpublished results is to document the apparent consistent transformation of 2-line to 6-line ferrihydrite under both aerobic and anoxic conditions.

The $77 \mathrm{~K}$ Mössbauer spectrum of the mineral residue from the bicarbonate, no AQDS, no P incubation (Fig. 10) showed distinct similarities to those observed for the 35 month $\mathrm{Ni}$ ferrihydrite (Fig. 5) and the 41 month Fe ferrihydrite (Fig. 9). All contained sextets associated with crystalline $\mathrm{Fe}^{3+}$ oxide (goethite primarily, with minor hematite), and a broadened central doublet, or collapsed sextet (superparamagnetic component) believed to represent 6-line ferrihydrite. What differed between samples were the apparent mass distributions of the individual phases as implied by spectral areas. The difference in the 6line ferrihydrite HFD distribution (Fig. 10b) from that of the aerobic samples was attributed to superparamagnetic behavioral effects, due to different media composition, redox potential, and organic contents of the aerobic and anaerobic incubations. This particular incubation with $\mathrm{CN} 32$ produced the lowest levels of $\mathrm{Fe}^{3+}$ reduction of all those studied by Fredrickson et al. (2001), and contained $<5 \% \mathrm{Fe}^{2+}$. This sorbed $\mathrm{Fe}^{2+}$ was barely visible by Mössbauer spectroscopy (* in Fig. 10 , the high field component). The microbiologically incubated Ni ferrihydrite displayed significantly more transformation of 2-line ferrihydrite to 6-line ferrihydrite and goethite than did the aerobically aged $\mathrm{Ni}$ ferrihydrite, in spite of higher $\mathrm{pH}$ and a much shorter overall equilibration time (e.g., 32 days vs. 15 months).

A common observation in studies of the microbiological transformation of ferrihydrite is the presence of residual ferrihydrite along with more crystalline, biogenic phases (Fredrickson et al. 1998; Fredrickson et al. 2001; Zachara et al. 2002). The crystalline character of this residual ferrihydrite has not been determined. Room-temperature Mössbauer measurements on the mineral residue from the PIPES, AQDS, no P incubation with Ni ferrihydrite (Fredrickson et al. 2001) showed the presence of magnetite (sextets) and residual ferrihydrite (central doublet) in the 32 day mineral residue (Fig. 11a). The biogenic material, that exhibited a $\mathrm{Fe}^{2+} / \mathrm{Fe}^{3+}$ ratio of 0.2 , dis- 
played a Mössbauer spectrum similar to that of abiotically synthesized magnetite with $\mathrm{Fe}^{2+} / \mathrm{Fe}^{3+}=0.25$ (Jolivet et al. 1992). The central doublet disappeared upon cooling the bioreduced sample to $77 \mathrm{~K}$ (Fig. 11b), indicating that all of the residual ferrihydrite associated with the magnetite was more crystalline than the 2-line ferrihydrite (note Mössbauer response of 2line ferrihydrite to $77 \mathrm{~K}$, Fig. 5d). The crystalline ferrihydrite in the magnetite-containing sample exhibited a different response to $77 \mathrm{~K}$ than did that in all the other samples, where line broadening and partial collapse were the primary responses to cooling (e.g., Figs. 5e and 5f, 9b, 10a). The crystalline ferrihydrite that was present with magnetite apparently exhibited a different magnetic ordering temperature than did 6-line ferrihydrite that formed at lower $\mathrm{Fe}^{2+}$ concentrations.

\section{DISCUSSION}

\section{Formation of 6-line ferrihydrite under oxic conditions}

2-line Ni ferrihydrite. The transformation of freshly precipitated 2-line $\mathrm{Ni}$ ferrihydrite to goethite and/or hematite was slow under the conditions of this study. Past research (Cornell and Schwertmann 1996) has shown that coprecipitated metal cations (e.g., Co, Ni) retard ferrihydrite crystallization. Most studies of ferrihydrite crystallization have been carried out in more dilute ferrihydrite suspensions at higher temperature (Cornell et al. 1992; Ford et al. 1997; Ford et al. 1999) and higher $\mathrm{pH}$ (Cornell et al. 1992). Transformation rates are more rapid under such conditions. For example, at $70^{\circ} \mathrm{C}$ and $\mathrm{pH} 12$, $\sim 40 \%$ of Ni ferrihydrite crystallized in one day (Cornell et al. 1992), making it difficult to identify changes in ferrihydrite structure. Following such transformations at lower temperature, as was done here, provided an opportunity to follow progressive changes in structure (ordering) of the Ni ferrihydrite coprecipitate. In addition, our use of concentrated, initially circumneutral ferrihydrite suspensions (close to the $\mathrm{pH}$ of zero net charge of ferrihydrite), encouraged the initial aggregation of ferrihydrite particles (Schwertmann et al. 1999, Banfield et al. 2000) that appears necessary for thermodynamic transformation to more stable hematite (Schwertmann et al. 1999) and possibly goethite (Banfield et al. 2000).

Structural changes in the 2-line Ni ferrihydrite were clearly evident as aging proceeded (Figs. 1 and 5). Partial conversion of 2-line Ni ferrihydrite to 6-line Ni ferrihydrite occurred over the first 17 months of aging (Figs. 1 and 5). The presence of a "collapsed" sextet in the 17 month 77 K Mössbauer spectrum, not present in the "fresh" sample, demonstrated such a change. We attribute the "collapsed" sextet to 6-line ferrihydrite because goethite and hematite were not evident in the XRD pattern (in which the XRD detection limit is approximately 5 mass \%). With further aging, the 6-line Ni ferrihydrite content increased considerably. The increase in 6-line Ni ferrihydrite content was clearly evident from comparison of the XRD spectra of the 17 month (Fig. 1b) and 38 month (Fig. 2c) samples. Mössbauer modeling (Fig. 6b) showed that 6-line Ni ferrihydrite accounted for approximately 65 mass percent of the 35 month sample.

The increase in 6-line Ni ferrihydrite content was paralleled by small increases in goethite and hematite. Goethite and hematite increased from a combined percentage of approximately
$5 \%$ in the 17 month sample to $22 \%$ in the 35 month sample. The goethite-to-hematite ratio in the 35 month sample was $1: 1$ whereas the ratio was $4: 1$ for a dilute 2-line Fe ferrihydrite suspension $(0.025 \mathrm{~mol} / \mathrm{L})$ aged for 15 months at a similar $\mathrm{pH}$ and temperature (Schwertmann and Murad 1983). The transformation of 2-line to 6-line ferrihydrite, formation of only small amounts of goethite and hematite, and low goethite-to-hematite ratio, collectively indicate that aggregation-based crystal growth (crystallization within ferrihydrite aggregates) was responsible for 6-line ferrihydrite formation. The high suspension density of ferrihydrite and the moderate ionic strength used in our experiments may have been important in enhancing aggregation. Our study could not discriminate whether hematite was formed from 2-line ferrihydrite directly or via 6-line ferrihydrite. Both 2-line ferrihydrite and 6-line ferrihydrite can transform to hematite under various conditions (Schwertmann et al. 1999).

2-line Fe ferrihydrite. Aging experiments were performed with 2-line Fe ferrihydrite to identify the impacts of $\mathrm{Ni}$, by comparison, on ferrihydrite transformation. Schwertmann and Murad (1983) aged 2-line Fe ferrihydrite at $24^{\circ} \mathrm{C}$ for 31 months and characterized the transformation products. Our study differed from the Schwertmann and Murad (1983) experiments in that: (1) a higher suspension density of ferrihydrite was used here $(0.42 \mathrm{~mol} / \mathrm{L}$ vs. $0.025 \mathrm{~mol} / \mathrm{L}),(2)$ the suspension $\mathrm{pH}$ was not adjusted, and (3) the ferrihydrite was aged in $0.1 \mathrm{~mol} / \mathrm{L}$ $\mathrm{NaClO}_{4}$. The $\mathrm{pH}$ of our "fresh" suspension was 7.2 and that of the 41 month aged sample was 2.9. In contrast, Schwertmann and Murad (1983) maintained a nearly constant suspension $\mathrm{pH}$. The low final $\mathrm{pH}$ of our suspensions strongly encouraged ferrihydrite dissolution over the later stages of aging.

The aging of freshly precipitated 2-line Fe ferrihydrite yielded a different product suite than did that of the 2-line $\mathrm{Ni}$ ferrihydrite. Goethite was generated in larger quantities than was 6-line ferrihydrite (Figs. 7b and 7c) in the Fe ferrihydrite suspension, and hematite was present in small concentrations (Fig. 9c). The formation of goethite increased with aging duration and lower suspension $\mathrm{pH}$. The enhanced formation of goethite indicated that dissolution of 2-line ferrihydrite and solution phase precipitation (Feitknecht and Michaelis 1962) was dominant over aggregation-induced crystallization. Apparently, the presence of coprecipitated $\mathrm{Ni}^{2+}$ in the $\mathrm{Ni}$ ferrihydrite moderated $\mathrm{pH}$ change and retarded the dissolution process.

Our finding of appreciable amounts of 6-line ferrihydrite was unexpected because no such phase was observed in the study of Schwertmann and Murad (1983), wherein the conversion products were goethite and hematite in various ratios. The goethite-to-hematite ratio increased from 0.33 to 7.3 as the $\mathrm{pH}$ of the suspension decreased from 7 to 3 , the $\mathrm{pH}$ range of the present study. Apparently, the high degree of ferrihydrite conversion to goethite and hematite observed by Schwertmann and Murad (81 to $96 \%$ ) perhaps precluded the detection, if any, of 6-line ferrihydrite.

Aggregation/crystallization effects. We observed significant differences in suspension $\mathrm{pH}$ and mineralogical products after aging 2-line $\mathrm{Fe}$ and $\mathrm{Ni}$ ferrihydrites under aerobic conditions. The stochiometric conversion of ferrihydrite (approximated as $\mathrm{Fe}(\mathrm{OH})_{3}$ for simplicity) to goethite or hematite 
involves no $\mathrm{pH}$ change:

$$
\begin{aligned}
& \mathrm{Fe}(\mathrm{OH})_{3(\mathrm{~s})}=\mathrm{FeOOH}_{(\mathrm{s})}+\mathrm{H}_{2} \mathrm{O} \\
& \mathrm{Fe}(\mathrm{OH})_{3(\mathrm{~s})}=0.5 \mathrm{Fe}_{2} \mathrm{O}_{3(\mathrm{~s})}+1.5 \mathrm{H}_{2} \mathrm{O}
\end{aligned}
$$

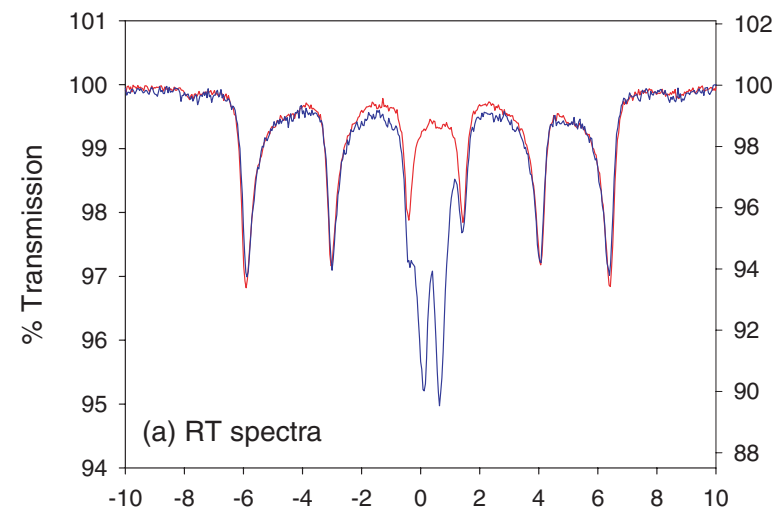

The proton condition of the 2-line ferrihydrite suspension at the initiation of the experiment $(\mathrm{pH} 7)$ may be defined as:

$\mathrm{TOT}_{\mathrm{H}}=2\left[\mathrm{FeOH}_{2}^{+}\right]_{\mathrm{s}}+[\mathrm{FeOH}]_{\mathrm{s}}+\left[\mathrm{H}^{+}\right]_{\mathrm{aq}}-\left[\mathrm{FeO}^{-}\right]_{\mathrm{s}}-\left[\mathrm{OH}^{-}\right]_{\mathrm{aq}}(3)$
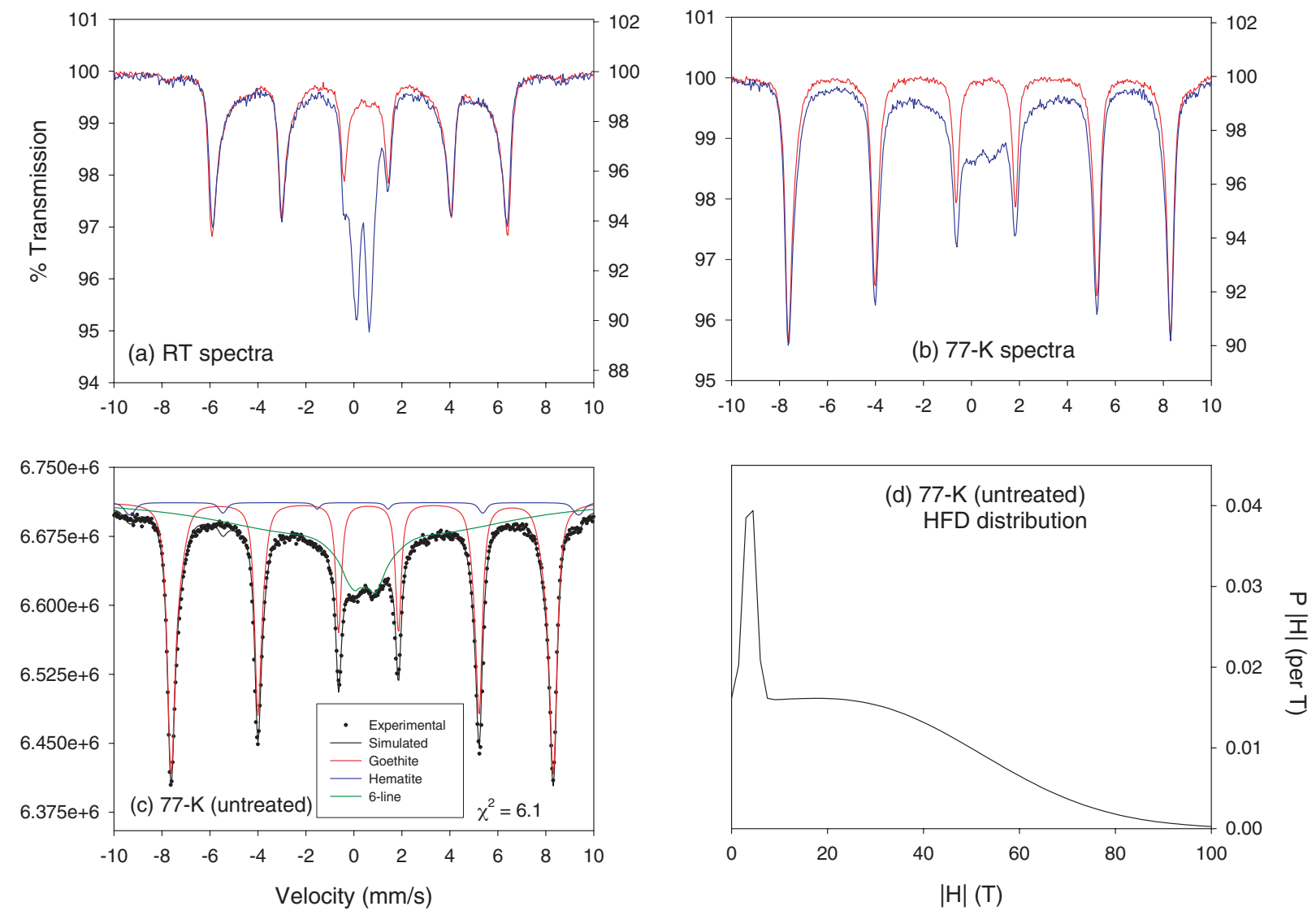

FIGURE 9. Room temperature (a) and liquid nitrogen (b) Mössbauer spectra of 41 month aged samples, the untreated sample is recorded in blue and the $24 \mathrm{~h}$ AAO treated sample in red. (c) Spectral modeling of the $77 \mathrm{~K}$ Mössbauer spectrum of the untreated sample, and (d) the HFD distribution used for 6-line ferrihydrite.
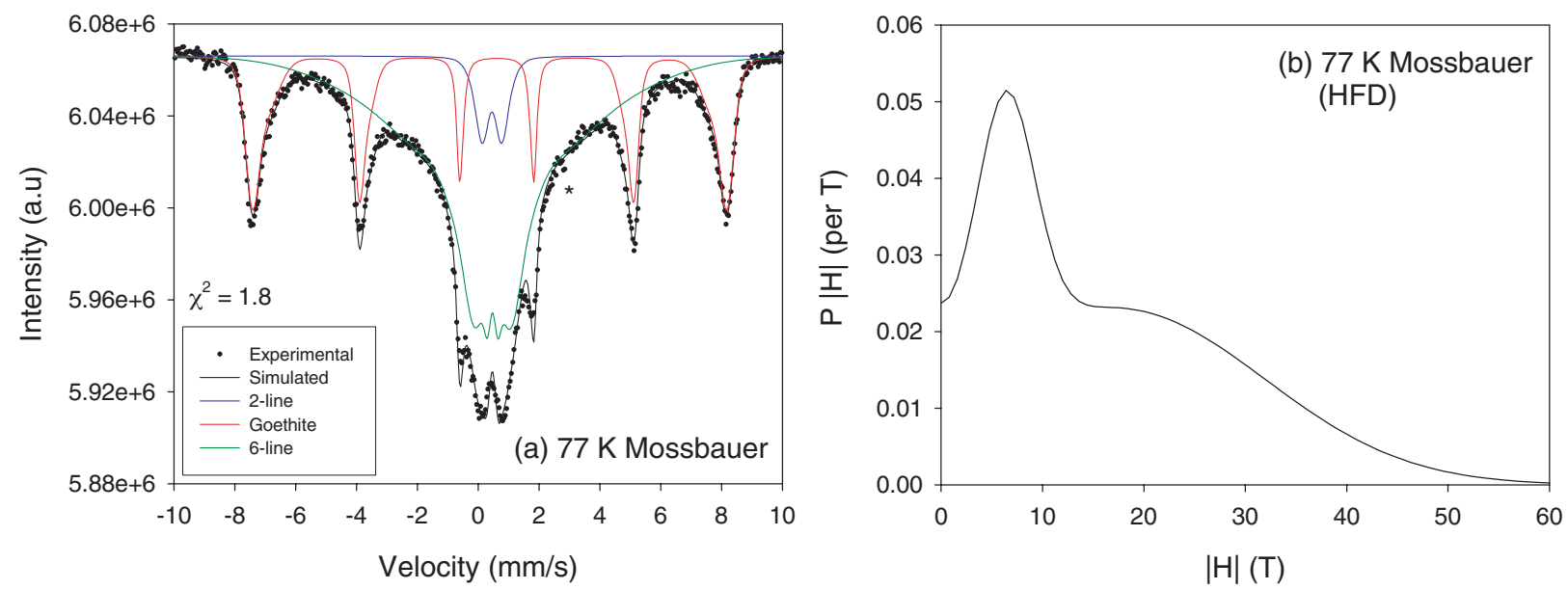

FIGURE 10. Mineral products resulting from the incubation of Ni ferrihydrite with CN32 in bicarbonate buffer without P and AQDS. (a) Experimental and simulated $77 \mathrm{~K}$ Mössbauer spectra and (b) HFD distribution of 6-line ferrihydrite. 
where $\left[\mathrm{FeOH}_{2}^{+}\right]_{\mathrm{s}},[\mathrm{FeOH}]_{\mathrm{s}}$ and $\left[\mathrm{FeO}^{-}\right]_{\mathrm{s}}$ are hydroxylated surface sites on ferrihydrite. The aging and recrystallization of 2line ferrihydrite involves a decrease in surface area, and an increase in structural $\mathrm{Fe}-\mathrm{O}-\mathrm{Fe}$ bonds through condensation of hydroxylated surface sites that are in relatively high concentration $(0.2 \mathrm{~mol}$ of $\mathrm{FeOH} / \mathrm{mole}$ of $\mathrm{Fe}$, Dzombak and Morel 1990). Because the initial $\mathrm{pH}$ of the aging solution $(\mathrm{pH}=7.2)$ was below that of the PZC ( $\mathrm{pH} \sim 8)$ of the oxide surface (e.g., $\left.\left[\mathrm{FeOH}_{2}^{+}\right]_{\mathrm{s}}>\left[\mathrm{FeO}^{-}\right]_{\mathrm{s}}\right)$, surface-site condensation leads to acidification of the recrystallizing mineral suspension:

$$
\mathrm{FeOH}_{2(\mathrm{~s})}^{+}+\mathrm{FeOH}_{(\mathrm{s})}=\mathrm{Fe}-\mathrm{O}-\mathrm{Fe}_{(\mathrm{s})}+\mathrm{H}_{(\mathrm{aq})}^{+}+\mathrm{H}_{2} \mathrm{O}
$$

Proton release in our experiments was particularly pronounced because of (1) the high suspension concentration of 2-line ferrihydrite $(0.42 \mathrm{~mol} / \mathrm{L})$, and concomitant high concentration of $\mathrm{FeOH}_{2}{ }^{+}$, and (2) the low buffering capacity of the suspension provided only by surface reactions of the 2-line ferrihydrite and oxide conversion products of lower surface area and site density. This $\mathrm{pH}$ decrease that was promoted by both 6-line ferrihydrite and goethite formation further encouraged the conversion to goethite by enhancing the solubility and dissolution of ferrihydrite. A sizable $\mathrm{pH}$ decrease was also observed in the aging/transformation of 2-line ferrihydrite to hematite at $92^{\circ} \mathrm{C}$ by Combes et al. (1990), who termed the process

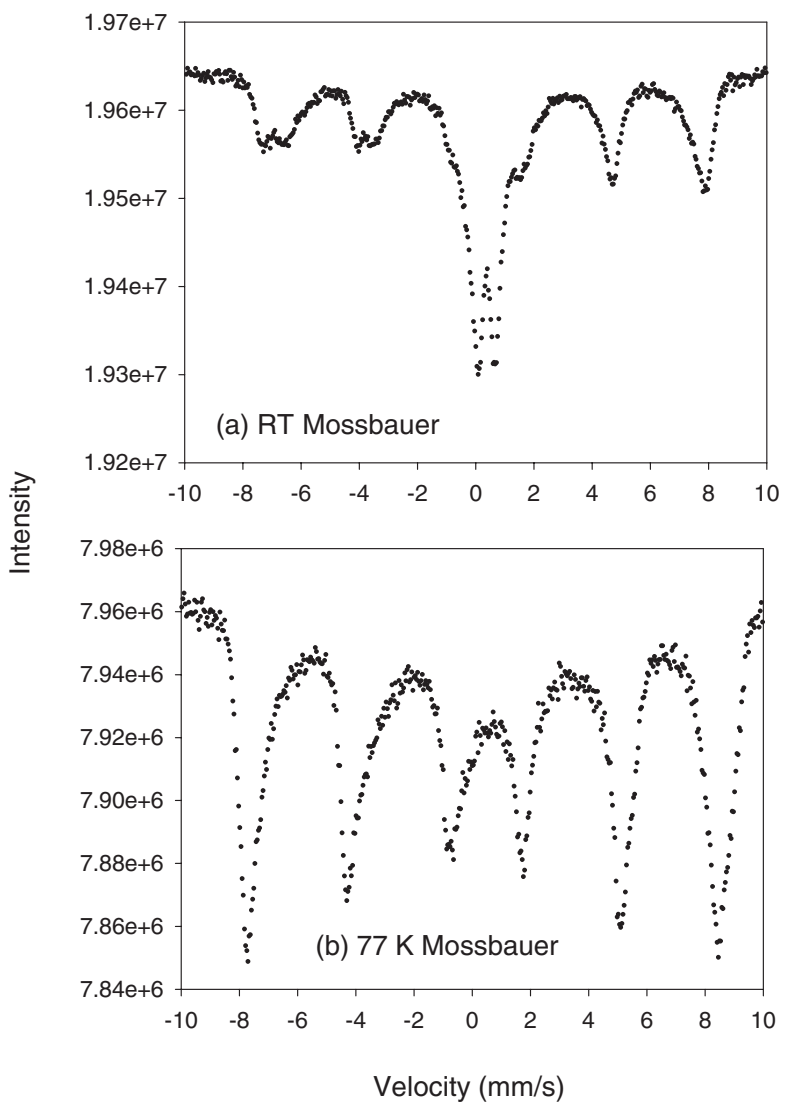

FIGURE 11. Mineral products resulting from the incubation of $\mathrm{Ni}$ ferrihydrite with CN32 in PIPES buffer with AQDS (a) Room temperature Mössbauer spectrum and (b) $77 \mathrm{~K}$ Mössbauer spectrum. deprotonation-oxalation.

Coprecipitated $\mathrm{Ni}$ retarded $\mathrm{pH}$ change and conversion to the more crystalline phases goethite and hematite. We speculate that coprecipitated $\mathrm{Ni}$ occupied hydroxylated surface sites on the ferrihydrite:

$$
\mathrm{FeOH}_{(\mathrm{s})}+\mathrm{Ni}^{2+}{ }_{(\mathrm{aq})}=\mathrm{FeONi}_{(\mathrm{s})}^{+}+\mathrm{H}_{(\mathrm{aq})}^{+}
$$

The proton evolved in (5) was neutralized during the hydrolytic synthesis of HFO. This coprecipitated Ni was present in a concentration that would saturate approximately $25 \%$ of the surface sites. Coprecipitated Ni retarded the progress of reaction (4) by decreasing the surface concentrations of $\mathrm{FeOH}_{2(\mathrm{~s})}^{+}$ and $\mathrm{FeOH}_{(\mathrm{s})}$ through a combination of mass action and electrostatic effects. The net result was to reduce the formation of new Fe-O-Fe bonds, to decrease the extent of $\mathrm{pH}$ change, and to minimize goethite formation under aerobic conditions.

\section{Formation of 6-line/“"well” organized ferrihydrite under anaerobic conditions}

The observation of rapid formation of 6-line ferrihydrite and goethite from $\mathrm{Ni}$ ferrihydrite under anaerobic, ferrigenic conditions as observed in the bicarbonate, no AQDS, no P incubation (Fig. 10) was a curious one. In no other biotransformation study performed by our group [e.g., Fredrickson et al. 1998; Fredrickson et al. 2001; Zachara et al. 2002; Fredrickson et al. (2003)] has 6-line ferrihydrite appeared in such high concentration as a product phase. Previously, we have observed rapid recrystallization of 2-line ferrihydrite to hematite and goethite under $\mathrm{Fe}^{3+}$-reducing conditions promoted by $\mathrm{CN} 32$ at circumneutral $\mathrm{pH}$ when the electron donor concentration was low $(0.5 \mathrm{mmol} / \mathrm{L})$ and $\mathrm{Fe}^{3+}$ suspension density was high $(150$ $\mathrm{mmol} / \mathrm{L}$ ) (Zachara et al. 2002). These conditions promoted the slow and incomplete reduction of ferrihydrite. Goethite formation was attributed to the sorption of biogenic $\mathrm{Fe}^{2+}$ on aggregated ferrihydrite, which appeared to greatly catalyze recrystallization. Such catalytic effects have been observed by others in abiotic, $\mathrm{Fe}^{2+}$-spiked systems (Fischer 1972; Andreeva et al. 1995; Fredrickson et al. 2003), but the mechanisms involved have not been adequately explained. The addition of $\mathrm{CN} 32$ (ca $>10^{6}$ cells $/ \mathrm{mL}$ ) to ferrihydrite suspensions at $\mathrm{pH} 7$ induces rapid and complete flocculation of the ferrihydrite, possibly implying a greater degree of aggregation of the ferrihydrite nano-particles in microbe-containing suspensions. The significant presence of 6-line ferrihydrite in Figure 10 is partially explained by the effect of $\mathrm{Ni}$, which retards both recrystallization (Cornell et al. 1992) and bioreduction (Fredrickson et al. 2001), and possibly favors 6-line ferrihydrite formation through indirect or competitive kinetic effects.

The absence of the doublet in the $77 \mathrm{~K}$ spectrum in the magnetite-containing sample (Fig. 11b) implied that the residual ferrihydrite was significantly different from the 2-line form (Fig. 5d). This residual phase is more crystalline/organized than 2line ferrihydrite. This "well" organized ferrihydrite may be an intermediate phase in the transformation of ferrihydrite to magnetite, or it may be an alternative product resulting from the reaction of $\mathrm{Fe}^{2+}$ with ferrihydrite (e.g., Fischer 1972; Fredrickson et al. 2003; Ardizzone and Formaro 1983). The 
rapid formation (in days) of 6-line ferrihydrite and magnetite (in the presence of AQDS and CN32; Fredrickson et al. 2001), as compared to months in abiotic studies suggests that the biogenic $\mathrm{Fe}^{2+}$ flux rate accelerated 2-line ferrihydrite transformation to 6-line ferrihydrite.

\section{ACKNOWLEDGMENTS}

This research was supported by the Geosciences Research Program, Office of Basic Energy Sciences, U.S. Department of Energy (DOE). Mössbauer, XRD, and TEM measurements were performed within the DOE/OBER Environmental and Molecular Sciences Laboratory (EMSL). Pacific Northwest National Laboratory is operated for DOE by Battelle Memorial Institute under contract DE-AC06 76RLO1830. We thank John Jambor, D. Rancourt, and anonymous reviewers for their help in improving the manuscript.

\section{REFERENCES CITED}

Ainsworth, C.C., Pilon, J.L., Gassman, P.L., and Van Der Sluys, W.G. (1994) Cobalt, cadmium, and lead sorption to hydrous iron oxide: Residence time effect. Soil Science Society America Journal, 58, 1615-1623.

Andreeva, D., Mitov, I., Tabakova, T., Mitrov, V., and Andreev, A. (1995) Influence of $\mathrm{Fe}^{2+}$ on the transformation of ferrihydrite into goethite in acid medium. Materials Chemistry and Physics, 41, 146-149.

Ardizzone, S. and Formaro, L. (1983) Temperature induced phase transformation of metastable $\mathrm{Fe}(\mathrm{OH})_{3}$ in the presence of ferrous ions. Materials Chemistry and Physics, 8, 125-133.

Banfield, J.F., Welch, S.A., Zhang, H., Ebert, T.T., and Penn, R.L. (2000) Aggregationbased crystal growth and microstructure development in natural iron oxyhydroxides biomineralization products. Science, 289, 751-754

Carlson, L. and Schwertmann, U. (1981) Natural ferrihydrites in surface deposits from Finland and their association with silica. Geochimica et Cosmochimica Acta, 45, 421-429.

Chukrov, F.V., Zvyagin, B.B., Ermilova, L.P., and Balashova, V.V. (1973) Ferrihydrite, Izvestya Akademii Nauk, SSSR. Seriya Geologiya, 4, 23-33.

Combes, J.M., Manceau, A., and Calas, G. (1990) Formation of ferric oxides from aqueous solutions: A polyhedral approach by X-ray absorption spectroscopy. II. Hematite formation from ferric gels. Geochimica et Cosmochimica Acta, 54, 1083.

Cornell, R.M. and Giovanoli, R. (1985) Effect of solution conditions on the proportion and morphology of goethite formed from ferrihydrite. Clays and Clay Minerals, 33, $424-432$

Cornell, R.M. and Schwertmann, U. (1996) The Fe Oxides: Structure, Properties, Reactions, Occurrences, and Uses. VCH. Weinheim, Germany.

Cornell, R.M., Giovanoli, R., and Schneider, W. (1992) The effect of nickel on the conversion of amorphous $\mathrm{Fe}^{3+}$ hydroxide into more crystalline iron oxides in alkaline media. Journal of Chemical Technology Biotechnology, 53, 73-79.

Dang, M.Z., Rancourt, D.G., Dutrizac, J.E., Lamarche, G., and Provencher, R. (1998) Interplay of surface conditions, particle size, stoichiometry, cell parameters, and magnetism in synthetic hematite-like minerals. Hyperfine Interactions, 117, 271319 .

Drits, V.A., Sakharov, B.A., Salyn, A.L., and Manceau, A. (1993) Structural model of ferrihydrite. Clay Minerals, 28, 185-207.

Dzombak, D.A. and Morel, F.M.M. (1990) Surface Complexation Modeling: Hydrous Ferric Oxide. Wiley, New York.

Eggleton, R.A. and Fitzpatrick, R.W. (1988) New data and a revised structural model for ferrihydrite. Clays and Clay Minerals, 36, 111-124.

Feitknecht, W. and Michaelis, W. (1962) Uber die hydrolyze von $\mathrm{Fe}^{3+}$-perchlorat-lösungen. Helvetica Chimica Acta, 26, 212-214

Fey, M.V. and LeRoux, J. (1977) Properties and quantitative estimation of poorly crystalline components in sesquioxide soil clays. Clays and Clay Minerals, 25, 285-294.

Fischer, W.R. (1972) Die Wirkung von zweiwertigem Eisen auf Losung and Umwandlung von $\mathrm{Fe}^{3+}$-hydroxiden. In E. Schlichting and U. Schwertmann, Eds., Pseudogley and gley. Transactions of Commissions V and VI International Society of Soil Science, VCH, Weinheim, 37-44.

Fischer, W.R. and Schwertmann, U. (1975) The formation of hematite from amorphous $\mathrm{Fe}^{3+}$ hydroxide. Clays and Clay Minerals, 23, 33-37.

Ford, R.G., Bertsch, P.M., and Kevin, F. (1997) Changes in transition and heavy metal partitioning during hydrous iron oxide aging. Environmental Science and Technology, 31, 2028-2033.

Ford, R.G., Kemner, K.M., and Bertsch, P.M. (1999) Influence of sorbate-sorbent interactions on the crystallization kinetics of nickel- and lead-ferrihydrite coprecipitates. Geochimica et Cosmochimica Acta, 63, 39-48.

Fredrickson, J.K., Zachara, J.M., Kennedy, D.W., Dong, H., Onstottt, T.C., Hinman, N.W., and Li, S. (1998) Biogenic Fe mineralization accompanying the dissimilatory reduc- tion of hydrous ferric oxide by a ground water bacterium. Geochimica et Cosmochimica Acta, 62, 3239-3257.

Fredrickson, J.K., Zachara, J.M., Kukkadapu, R.K., Gorby, Y.A., Smith, S.C., and Brown, C.F. (2001) Biotransformation of Ni-substituted hydrous ferric oxide by an $\mathrm{Fe}^{3+}$ reducing bacterium. Environmental Science and Technology, 35, 703-712.

Fredrickson, J.K., Kota, S.A., Kukkadapu, R.K., Liu, C., and Zachara, J.M. (2003) Influence of electron donor/acceptor concentrations on hydrous ferric oxide (HFO) bioreduction. Biodegradation, 14, 91-103.

Janney, D.E., Cowley, J.M., and Buseck, P.R. (2000) Transmission electron microscopy of synthetic 2- and 6-line ferrihydrite. Clays and Clay Minerals, 48, 111-119.

Johnston, J.H. and Lewis, D.G. (1983) Adetailed study of the transformation of ferrihydrite to hematite in an aqueous medium at $92^{\circ} \mathrm{C}$. Geochimica et Cosmochimica Acta, 47 , $1823-1831$.

Jolivet, J.P., Belleville, P., Tronc, E., and Livage, J. (1992) Influence of $\mathrm{Fe}^{2+}$ on the formation of the spinel iron-oxide in alkaline medium. Clays and Clay Minerals, 40, 531539.

Kukkadapu, R.K., Zachara, J.M., Smith, S.C., Fredrickson, J.K., and Liu, C. (2001) Dissimilatory bacterial reduction of $\mathrm{Al}$-substituted goethite in subsurface sediments. Geochimica et Cosmochimica Acta, 65, 2913-2924.

Murad, E. (1996) Magnetic properties of microcrystalline $\mathrm{Fe}^{3+}$ oxides and related materials as reflected in their Mössbauer spectra. Physics and Chemistry of Minerals, 23, 248-262.

Nevin, K.P. and Lovely, D.R. (2000) Potential for nonenzymatic reduction of $\mathrm{Fe}^{3+}$ via electron shuttling in subsurface sediments. Environmental Science and Technology, 34, 2472-2478.

Pankhurst, Q.A. and Pollard, R.J.(1992) Structural and magnetic properties of ferrihydrite. Clays Clay Minerals, 40, 268-272.

Rancourt, D.G. (1988) Mössbauer spectroscopy in clay science. Hyperfine Interactions, $117,3-38$.

Rancourt, D.G. and Ping, J.Y. (1991) Voigt-based methods for arbitrary-shape static hyperfine parameter distribution in Mössbauer spectroscopy. Nuclear Instruments and Methods in Physics Research B, 58, 85-97.

Rancourt, D.G., Ping, J.Y., and Berman, R.G. (1994) Mössbauer spectroscopy of minerals III. Octahedral-site $\mathrm{Fe}^{2+}$ quadrupole splitting distributions in phlogopite-annite series. Physics and Chemistry of Minerals, 21, 258-267.

Rancourt, D.G., Fortin, D., Pichler, T., Thibault, P-J., Lamarche, G., Morris, R.V., and Mercier, P.H.J. (2001) Mineralogy of a natural As-rich hydrous ferric oxide coprecipitate formed by mixing of hydrothermal fluid and sea water: Implications regarding surface complexation and color banding in ferrihydrite deposits. American Mineralogist, 86, 834-851.

Schulze, D.G. (1994) Differential X-ray diffraction analysis of soil minerals. In J.E. Amonette and L.W. Zelazny, Eds., Quantitative methods in soil mineralogy, (SSSA miscellaneous publication), Chapter 13, 412-428.

Schwertmann, U. (1959) Die fraktionierte Extraktion der freien Eisenoxyde in Böden, ihre mineralogischen Formen und ihre Entstehyngwweisen. Zeitschrift Pflanzenernährung Dünger Bodenkunde, 84, 194-204.

Schwertmann, U. and Cornell, R.M. (1991) Iron Oxides in the Laboratory: Preparation and Characterization, 91 p. VCH Publishers, Weinheim, Germany.

Schwertmann, U. and Fischer, W.R. (1966) Zur Bildung von $\alpha$-FeOOH and $\alpha-\mathrm{Fe}_{2} \mathrm{O}_{3}$ au amorphen $\mathrm{Fe}^{3+}$-hydroxid. Zeitschrift Allgemeine Chemie, 346, 137-142.

- (1973) Natural "amorphous" ferric hydroxide. Geoderma, 10, 237-247.

Schwertmann, U. and Murad, E. (1983) Effect of $\mathrm{pH}$ on the formation of goethite and hematite from ferrihydrite. Clays and Clay Minerals, 4, 277-284.

Schwertmann, U., Schulze, D.G., and Murad, E. (1982) Identification of ferrihydrite in soils by dissolution kinetics, differential X-ray diffraction, and Mössbaue spectroscopy. Soil Science Society America Journal, 46, 869-874.

Schwertmann, U., Friedl, J., and Stanjek, H. (1999) From $\mathrm{Fe}^{2+}$ ions to ferrihydrite and then to hematite. Journal of Colloid and Interface Science, 209, 215-223.

Stanjek, H. and Weidler, P.G. (1992) The effect of dry heating on the chemistry, surface area, and oxalate solubility of synthetic 2-line and 6-line ferrihydrites. Clay Minerals, 27, 397-412.

Towe, K.M. and Bradley, W.F. (1967) Mineralogical constitution of colloidal "hydrous ferric oxides". Journal of Colloid and Interface Science, 24, 384-392.

Weidler, P. (1995) Oberflächen synthetischer eisenoxide. Dissertation, Technical University. München, 108 p.

Zachara, J.M., Kukkadapu, R.K., Fredrickson J.K., Gorby, Y.A., and Smith, S.C. (2002) Biomineralization of poorly crystalline $\mathrm{Fe}^{3+}$ oxides by dissimilatory metal reducing bacteria (DMRB). Geomicrobiology Journal, 19, 179-207.

Zhao, J., Huggins, F.E., Feng, Z., and Huffman, G. (1996) Surface-induced superparamagnetic relaxation in nanoscale ferrihydrite particles. Physical Review B, 54, 3403-3407.

MANUSCRIPT RECEIVED AUGUST 8, 2002

MANUSCRIPT ACCEPTED JUNE 18, 2003

MANUSCRIPT HANDLED BY JOHN JAMBOR 